\title{
Effect of Fruiting Spur Length and Spraying Seaweed Extract on Yield and Berries Quality of Early Sweet Grapevines
}

\author{
Ali H. Ali and Moumen A. Kh. Mohamed
}

Hort. Dept. Fac. of Agric. Minia Univ. Egypt

Received on: 23/10/2016

Accepted for publication on: 22/11/2016

\begin{abstract}
This study was carried out during 2014 and 2015 seasons to examine the effect of three levels of fruiting spur length (two, three or four eyes/ spur) and four concentrations of seaweed extract $(0.05,0.1,0.2$ or $0.4 \%)$ on the percentages of bud burst and fruiting buds, growth, vine nutritional status, yield and berries quality of Early sweet grapevines grown under Minia region conditions.

Increasing fruiting spur length from two to four eyes resulted in a gradual reduction on bud burst $\%$, leaf area, berry setting $\%$, yield, cluster weight and dimensions, shot berries $\%$ and total acidity $\%$, while fruiting buds $\%$, shoot length, number of leaves / shoot, percentages of $\mathrm{N}, \mathrm{P}, \mathrm{K}, \mathrm{Mg}$ and $\mathrm{Ca}$, berry weight and dimensions, T.S.S \%, total sugars $\%$ and T.S.S./acid ratio were progressively enhanced. Foliar application of seaweed extract at $0.05 \%$ to $0.4 \%$ resulted in stimulating all the investigated characteristics except shot berries $\%$ and total acidity $\%$ over the check treatment. The effect was in proportional to the increase in concentrations of seaweed extract. All the studied parameters were unaffected by increasing concentrations of seaweed extract from 0.2 to $0.4 \%$.

For promoting the yield of Early Sweet grapevines quantitatively, it is suggested to prune the vines leaving 30 fruiting spurs $\mathrm{x}$ two eyes/ each besides spraying seaweed extract three times at $0.2 \%$. Pruning to leave 15 fruiting spurs $\mathrm{x}$ four eyes/ each plus spraying seaweed extract three times at $0.2 \%$ gave the best results with regard to quality of the berries.
\end{abstract}

Keywords: Early sweet grapevines, Fruiting spur length, Seaweed extract, Yield and berries quality.

\section{Introduction}

Early Sweet grapevines as a newly introduced grapevine cv. is still need additional studies and recommendations for the best horticultural practices that need to produce highest yield and improve quality of the berries. Generally, adjusting the length of fruiting spurs in various grapevine cvs. is considered the limiting factor that governed the yield. Supplying the vines with their requirements from different organic and inorganic nutrients at a balanced rate considered an important target for pomologists for improving both yield and quality of the berries. Nowadays using extracts of biofertilizers such as seaweed extract for grapevines has called the attention of workers as an alternative to synthetic chemicals. Seaweed extract has higher amounts of all nutrients, vitamins, antioxidants, amino acids, enzymes and natural hormones (James, 1994).

Previous studies showed that adjusting the length of fruiting spurs in most grapevine cvs. is considered the main reasons for promoting pro- 
ductivity (Abdel -Fattah et al., 1993; Kamel, 2002; Ahmed-Ansam, 2002; Awad, 2003; Nejatian, 2003; Jarad, 2004 and Abdel-Mohsen, 2013).

The results of Abd El- Wahab, (2007); Abd El- Hameed et al., (2010); El- Saman, (2010) and Gad El- Kareem and Abd El- Rahman, (2013) confirmed the beneficial effects of using seaweed extract on the yield in different grapevine cvs. Seleem-Basma and Ahmed, (2008) emphasized the previous results.

The target of this study was selecting the best length of fruiting spurs and concentrations of seaweed extract that are responsible for promoting yield and quality of Early Sweet grapevines growth under Minia region conditions.

\section{Materials and Methods}

This study was carried out during 2014 and 2015 seasons on forty five 5 -years old Early sweet grapevines grafted onto Paulsen grapevine rootstock grown in a private vine- yard located at El-Kayse village, Matay district, Minia Governorate where the texture of the soil is clay, well drained and with a water table depth not less than two meters (Table 1). Analysis of the soil was done according to Wilde et al., (1985). Vines are spaced at 2.5 (between vines)x $3 \mathrm{~m}$. (between rows) (560 vines per/fed.). The selected vines were chosen as uniform in vigour as possible. Winter pruning was done on the first week of Jan. during both seasons and the vine load for all the selected vines was adjusted to 60 eyes/vine and fruiting spur length was varied according to the present treatments. Gable supporting system was followed. Surface irrigation system was followed using Nile water. Except those dealing with the present treatments (pruning and application of seaweed extract), all the selected vines received the usual horticultural practices which are commonly used in the vineyard.

Table 1. Analysis of the tested soil

\begin{tabular}{|l|c|}
\hline \multicolumn{1}{|c|}{ Constituents } & Values \\
\hline Particle size distribution & 2.11 \\
\hline Sand \% & 37.67 \\
\hline Slit \% & 60.22 \\
\hline Clay \% & Clay \\
\hline Texture \% & 7.5 \\
\hline pH $(1: 2.5$ extract) & 300 \\
\hline E.C. $(1: 2.5$ extract) ppm & 2.19 \\
\hline O.M. \% & 2.25 \\
\hline CaCO $\%$ & 0.10 \\
\hline Total $\%$ \% & 5.31 \\
\hline Available P (Olsen method, ppm) & 500.9 \\
\hline Available K (ammonium acetate, ppm) & \\
\hline EDTA extractable micronutrients (ppm) & 3.3 \\
\hline $\mathrm{Fe}$ & 4.0 \\
\hline $\mathrm{Mn}$ & 2.9 \\
\hline $\mathrm{Zn}$ & 0.9 \\
\hline $\mathrm{Cu}$ & \\
\hline
\end{tabular}


This experiment included the following fifteen treatments from various fruiting spur length and concentrations of seaweed extract:-

1- Leaving 30 fruiting spurs each spur with two eyes.

2- Leaving 30 fruiting spurs each spur with two eyes + spraying seaweed extract at $0.05 \%$.

3- Leaving 30 fruiting spurs each spur with two eyes + spraying seaweed extract at $0.1 \%$.

4- Leaving 30 fruiting spurs each spur with two eyes + spraying seaweed extract at $0.2 \%$.

5- Leaving 30 fruiting spurs each spur with two eyes + spraying seaweed extract at $0.4 \%$.

6- Leaving 20 fruiting spurs each spur with three eyes.

7- Leaving 20 fruiting spurs each spur with three eyes + spraying seaweed extract at $0.05 \%$.

8- Leaving 20 fruiting spurs each spur with three eyes + spraying seaweed extract at $0.1 \%$.

9- Leaving 20 fruiting spurs each spur with three eyes + spraying seaweed extract at $0.2 \%$.

10- Leaving 20 fruiting spurs each spur with three eyes + spraying seaweed extract at $0.4 \%$.
11- Leaving 15 fruiting spurs each spur with four eyes.

12- Leaving 15 fruiting spurs each spur with four eyes + spraying seaweed extract at $0.05 \%$.

13- Leaving 15 fruiting spurs each spur with four eyes + spraying seaweed extract at $0.1 \%$.

14- Leaving 15 fruiting spurs each spur with four eyes + spraying seaweed extract at $0.2 \%$.

15- Leaving 15 fruiting spurs each spur with four eyes + spraying seaweed extract at $0.4 \%$.

Each treatment was replicated three times, one vine per each. Therefore, forty-five uniform in vigour Early sweet grapevines were devoted for achieving of this experiment. Winter pruning at various spur lengths was conducted on the first week of Jan. during both seasons. Seaweed extract (Table 2) was sprayed three times at growth start (last week of Feb.), just after berry setting ( $1^{\text {st }}$ week of Apr.) and at one month later ( $1^{\text {st }}$ week of May). Triton $\mathrm{B}$ as a wetting agent was used at $0.05 \%$ for all solutions of seaweed extract and the spray was done till runoff (1-2 litre/vine). 
Table 2. Analysis of seaweed extract (according to James, 1994).

\begin{tabular}{|l|l|}
\hline \multicolumn{1}{|c|}{ Character } & values \\
\hline Moisture \% & 6.0 \\
\hline O.M. \% & $45-60$ \\
\hline Inorganic matter \% & $45-60$ \\
\hline Protein \% & $6-8$ \\
\hline Carbohydrates \% & $35-50$ \\
\hline Aliginic acid \% & $10-20$ \\
\hline Mannitol \% & $4-7$ \\
\hline Total N \% & $1.0-1.5$ \\
\hline P \% & $0.02-0.09$ \\
\hline K \% & $1.0-1.2$ \\
\hline Ca \% & $0.2-1.5$ \\
\hline S \% & $3-9$ \\
\hline Mg \% & $0.5-0.9$ \\
\hline Cu (ppm) & $1.0-6.0$ \\
\hline Fe (ppm) & $50-200$ \\
\hline Mn (ppm) & $5-12$ \\
\hline Zn (ppm) & $10-100$ \\
\hline B (ppm) & $20-100$ \\
\hline Mo (ppm) & $1-5$ \\
\hline Cytokinins \% & 0.02 \\
\hline IAA \% & 0.03 \\
\hline ABA \% & 0.01 \\
\hline
\end{tabular}

The present experiment was set up in a randomized complete block design (RCBD) with three replicates each consisted from one Early sweet grapevine. During both seasons, the following parameters were recorded:

1- Percentages of bud burst and fruiting buds.

2- Shoot length, number of leaves/shoot and leaf area in $\mathrm{cm}^{2}$ (Ahmed and Morsy, 1999).

3- Percentages of $\mathrm{N}, \mathrm{P}, \mathrm{K}, \mathrm{Mg}$ and $\mathrm{Ca}$ on dry weight basis of the leaves (Summer, 1985 and Wilde et al., 1985).
4- Percentage of berry setting, yield and cluster characteristics (weight, g.), length and shoulder in $\mathrm{cm})$.

5- Percentage of shot berries.

6- Berry weight (g.) and dimensions (longitudinal and equatorial, in cm) T.S.S\%, total acidity\%, total sugars\% (A.O.A.C, 2000) and T.S.S/ acid.

Statistical analysis was carried out using Randomized Complete Block Design (RCBD). Treatment means were compared using new L.S.D at 5\% (Mead et al., 1993). 


\section{Results and Discussion}

1- Behavior of Buds:

It is clear from the data in Table (3) that varying length of fruiting spurs had significant effect on the percentages of bud burst and fruiting buds. There was a gradual and significant reduction on the percentage of bud burst and at the same time caused a progressive promotion on the percentage of fruiting buds with increasing the length of fruiting spurs from two to four eyes. The promotion on the percentages of bud burst and fruiting buds was in proportional to the increase in concentrations of seaweed extract. The highest percentages of bud burst were recorded on the vines that pruned to leave 30 fruiting spurs $\mathrm{x} 2$ eyes plus spraying seaweed extract at $0.4 \%(86.5 \& 86.4) \%$ on the other hand leaving 15 fruiting spurs $x$ four eyes/ each plus spraying seaweed extract three times at $0.4 \%$ spurs gave the maximum fruiting spurs $(76.3 \& 78.4) \%$. As a general carrying out pruning leaving 2 to 4 eyes/fruiting spur besides spraying seaweed extract at 0.05 to $0.4 \%$ was significantly superior than carrying out pruning alone. Leaving 30 fruiting spurs $\mathrm{x} 2$ eyes during winter pruning without using seaweed extract gave the minimum value of fruiting buds $(71.4 \& 77.6) \%$. Percentages of bud burst were significantly minimized with leaving four eyes/fruiting spur without the application of seaweed extract $(79.4 \&$ $80.3) \%$. Similar results were announced during both seasons. teristics:
It is clear from the data in Table (3) that varying fruiting spurs length and concentrations of seaweed extract had an announced and significant differences on the three vegetative growth characteristics namely shoot length, number of leaves and leaf area. Winter pruning plus foliar application of seaweed extract at 0.05 to $0.4 \%$ was significantly accompanied with stimulating main shoot length and number of leaves per shoot and leaf area comparing with carrying out pruning alone (without using seaweed extract). Increasing the length of fruiting spurs from two to four eyes/spur caused a significant and gradual promotion on the shoot length and number of leaves/shoot and a reduction on the leaf area. Increasing concentrations of seaweed extract from 0.05 to $0.4 \%$ caused a progressive promotion on these growth aspects. Increasing concentrations of seaweed extract from 0.2 to $0.4 \%$ failed to show significant promotion on these growth aspects. Leaving 15 fruiting spurs $\mathrm{x}$ four eyes/ each plus spraying seaweed extract at $0.4 \%$ gave the maximum main shoot length and number of leaves/shoot. These results were true during both seasons.

\section{tion:}

3- Leaf chemical composi-

Data in Table (4) clearly show that varying length of fruiting spurs as well as concentrations of seaweed extract had significant effect on N, P, $\mathrm{K}, \mathrm{Mg}$ and $\mathrm{Ca}$. There was a gradual and significant promotion on these chemical components with increasing the length of fruiting spurs from two to four eyes/spur as well as concentrations of seaweed extract from 
0.05 to $0.4 \%$. Using seaweed extract at 0.05 to $0.4 \%$ plus pruning to various length of spur significantly was accompanied with enhancing all chemical constituents of the leaves over conducting pruning alone. Increasing seaweed extract concentrations from 0.2 to $0.4 \%$ had meaningless promotion on these nutrients. Leaving 15 fruiting spurs $\mathrm{x}$ four eyes per each plus foliar application of seaweed extract at 0.05 to $0.4 \%$ gave the highest values of these nutrients when comparing with using seaweed extract with the other pruning treatments. The highest values of $\mathrm{N}(2.56$ \& $2.46 \%), \mathrm{P}(0.38 \& 0.37 \%), \mathrm{K}$ (1.56 \& 1.49\%), $\mathrm{Mg}(0.95 \& 0.92 \%)$ and $\mathrm{Ca}(3.09 \& 2.99 \%)$ were recorded with leaving 15 fruiting spurs $\mathrm{x} 4$ eyes plus spraying seaweed extract at $0.4 \%$. Leaving 30 fruiting spurs $\mathrm{x}$ two eyes without using seaweed extract gave the lowest values. These results were true during both seasons.

\section{4- Berry setting, yield and cluster characteristics:}

Data in Tables (5\&6)clearly show that increasing the length of fruiting spurs with or without the application of seaweed extract at 0.05 to $0.4 \%$ caused a significant and gradual reduction on the percentage of berry setting, yield expressed in weight and number of clusters/ vine as well as weight, length and shoulder of cluster. Leaving four eyes/fruiting spur gave the lowest values. Treating the vines three times with seaweed extract at 0.05 to $0.4 \%$ caused a significant promotion on the percentage of berry setting, yield expressed in weight and number of clusters/vine as well as weight, length and shoulder of cluster over the check treatment. Leaving two to four eyes/ fruiting spurs along with the application of seaweed extract at 0.05 to $0.4 \%$ significantly was superior than carrying out pruning alone in improving these parameters. There was a gradual promotion on berry setting $\%$, yield and cluster aspects with increasing concentrations of seaweed extract from 0.05 to $0.4 \%$. Increasing concentrations of seaweed extract from 0.2 to $0.4 \%$ failed to show significant promotion on the percentage of berry setting, yield and cluster parameters. Using seaweed extract significantly alleviated the adverse effects of prolonging spur length on these parameters. From economical point of view, it is advised to prune Early sweet grapevines leaving thirty fruiting spurs each contains two eyes plus treating the vines with seaweed extract at 0.2 to promote berry setting, yield and cluster aspects. Under such promised treatment, berry setting reached $(11.2 \& 11.6 \%)$, while the yield was $(14 \& 16.4 \mathrm{~kg})$ and the cluster weight was (410 \& $409 \mathrm{~g})$, during both seasons, respectively. The lowest values were recorded when the vines were pruned to leaves 15 fruiting buds each contains four eyes without the application of seaweed extract. The present treatment had no significant effect on the number of cluster in 2014 season. These results (except number of clusters/vine) were true during both seasons.

\section{5- Percentage of shot berries:}

Data in Table (6) show that significant differences on the percentage of shoot berries were observed among the different fruiting 
spur lengths and concentrations of seaweed extract. There was a gradual and significant reduction on the percentage of shot berries with increasing the length of fruiting spurs from two to four eyes/fruiting spur at the same vine load. Treating the vines grown under these pruning treatments with seaweed extract at 0.05 to $0.4 \%$ significantly accompanied with reducing such unsuitable phenomenon comparing to the check treatment. The reduction on such parameter was in proportional to the increase in seaweed concentrations. Meaningless reduction on the percentage of shot berries was observed among the higher two concentrations namely 0.2 and $0.4 \%$. Leaving 30 fruiting spurs $\mathrm{x}$ two eyes without application of seaweed extract gave the maximum values $(8.1 \& 7.9 \%)$ during both seasons, respectively. The lowest values $(3.1 \& 2.9 \%)$ were recorded on the clusters harvested from vines pruned to leave 15 fruiting spurs $\mathrm{x}$ four eyes/spur plus treating the vines three times with seaweed extract at $0.4 \%$. These results were true during both seasons.

\section{6- Quality of berries:}

It is evident from the data in Tables (6\&7) that the seven parameters of berries quality namely weight, longitudinal and equatorial of berry, T.S.S\%, total acidity\%, T.S.S/acid and total sugars\% were significantly varied among the three fruiting spur length and the four concentrations of seaweed extract. Increasing the length of fruiting spurs from two to four eyes caused a significant and gradual promotion on quality of the berries in terms of increasing berry weight and dimensions, T.S.S\%,
T.S.S/acid and total sugars\% and decreasing total acidity $\%$. The same trend was observed with increasing seaweed extract concentrations from 0.05 to $0.4 \%$ using seaweed extract was significantly favourable in improving quality of the berries over the control treatment. Meaningless promotion on the quality of the berries was observed among the higher two concentrations namely 0.2 and $0.4 \%$ of seaweed extract. From economical point of view, it is suggested to prune Early sweet grapevines to leaves 15 fruiting spurs $\mathrm{x}$ four eyes/spur plus spraying seaweed extract at $0.2 \%$ three times for enhancing quality. Leaving 30 fruiting spurs $\mathrm{x}$ two eyes/ each without application of seaweed extract gave unfavorable effects on quality of the berries. These results were true during both seasons.

\section{Discussion:}

Adjusting the length of fruiting spur is necessary to balance growth and fruiting status/vine nutritional status and bud fertility (Tamura et al., 2002 and Ranspise et al., 2003).

These results are in agreement with those obtained by Abdel- Fattah et al., (1993); Ahmed-Ansam, (2002); Kamel, (2002); Nejatian, (2003); Awad, (2003); Jarad; (2004) and Abdel- Mohsen, (2013).

The higher content of seaweed extract from $\mathrm{N}, \mathrm{P}, \mathrm{K}, \mathrm{Mg}, \mathrm{Ca}, \mathrm{Zn}$, $\mathrm{Fe}, \mathrm{Mn}, \mathrm{Cu}, \mathrm{S}, \mathrm{Mo}$, pigments, amino acids, antioxidants, natural hormones and vitamins surely reflected on enhancing cell division, the biosynthesis of most organic foods and enzymes the tolerance of plants to biotic and abiotic stresses (James, 1994). 
These results are in agreement with those obtained by Abd-ElWahab, (2007); Ahmed and Abd ElAal, (2007), Seleem-Basma and Ahmed, (2008); El- Saman, (2010) and Gad El- Kareem and Abd ElRahman, (2013).

\section{Conclusion:}

For promoting yield of Early Sweet grapevines quantitatively, it is suggested to prune the vines leaving 30 fruiting spurs $\mathrm{x}$ two eyes/ each besides spraying seaweed extract three times at $0.2 \%$. Pruning to leaves 15 fruiting spurs $\mathrm{x}$ four eyes/ each plus spraying seaweed extract three times at $0.2 \%$ gave the best results with regard to quality of the berries.

Table 3. Effect of different fruiting spur lengths and concentrations of seaweed extract on the percentages of bud burst and fruiting buds and some vegetative growth characteristics of Early sweet grapevines during 2014 and 2015 seasons.

\begin{tabular}{|c|c|c|c|c|c|c|c|c|c|c|}
\hline \multicolumn{2}{|c|}{$\begin{array}{c}\text { Leaf area } \\
(\mathrm{cm})^{2}\end{array}$} & \multicolumn{2}{|c|}{$\begin{array}{c}\text { No. of leaves } \\
\text { /shoot }\end{array}$} & \multicolumn{2}{|c|}{$\begin{array}{c}\text { Shoot length } \\
(\mathrm{cm})\end{array}$} & \multicolumn{2}{|c|}{$\begin{array}{l}\text { Fruiting } \\
\text { buds \% }\end{array}$} & \multicolumn{2}{|c|}{$\begin{array}{c}\text { Bud burst } \\
\% \\
\end{array}$} & \multirow[t]{2}{*}{ Treatments } \\
\hline 2015 & 2014 & 2015 & 2014 & 2015 & 2014 & 2015 & 2014 & 2015 & 2014 & \\
\hline 102.0 & 101.0 & 13.3 & 13.0 & 114.3 & 110.0 & 72.6 & 71.9 & 86.1 & 85.9 & $\begin{array}{l}\text { 1- Leaving } 30 \text { fruiting spurs } x \\
2 \text { eyes }\end{array}$ \\
\hline 103.8 & 102.5 & 14.4 & 14.0 & 116.0 & 112.0 & 72.8 & 72.0 & 86.2 & 86.0 & $\begin{array}{l}\text { 2- Leaving } 30 \text { fruiting spurs } x \\
2 \text { eyes }+ \text { seaweed at } 0.05 \% \\
\end{array}$ \\
\hline 105.7 & 105.0 & 15.5 & 15.0 & 118.3 & 113.6 & 72.9 & 72.0 & 86.3 & 86.1 & $\begin{array}{ll}3- & \text { Leaving } 30 \text { fruiting spurs } x \\
& 2 \text { eyes }+ \text { seaweed at } 0.1 \% \\
\end{array}$ \\
\hline 107.7 & 107.0 & 16.6 & 16.3 & 119.3 & 115.0 & 72.9 & 72.0 & 86.3 & 86.2 & $\begin{array}{ll}4- & \text { Leaving } 30 \text { fruiting spurs } x \\
& 2 \text { eyes }+ \text { seaweed at } 0.2 \% \\
\end{array}$ \\
\hline 108.3 & 107.6 & 16.9 & 16.6 & 119.9 & 115.3 & 73.0 & 72.0 & 86.4 & 86.5 & $\begin{array}{ll}5-\quad \text { Leaving } 30 \text { fruiting spurs } x \\
& 2 \text { eyes }+ \text { seaweed at } 0.4 \%\end{array}$ \\
\hline 101.0 & 99.0 & 18.0 & 18.1 & 123.3 & 117.0 & 75.0 & 74.0 & 82.9 & 82.0 & $\begin{array}{ll}6- & \text { Leaving } 20 \text { fruiting spurs } \\
& \text { x3 eyes } \\
\end{array}$ \\
\hline 102.9 & 100.5 & 19.0 & 19.2 & 125.0 & 119.0 & 75.1 & 74.1 & 83.0 & 82.2 & $\begin{array}{l}\text { 7- Leaving } 20 \text { fruiting spurs } x \\
3 \text { eyes }+ \text { seaweed at } 0.05 \%\end{array}$ \\
\hline 105.0 & 102.0 & 20.0 & 20.3 & 127.3 & 121.0 & 75.2 & 74.2 & 83.0 & 82.3 & $\begin{array}{ll}8-\quad \text { Leaving } 20 \text { fruiting spurs } x \\
3 \text { eyes }+ \text { seaweed at } 0.1 \% \\
\end{array}$ \\
\hline 107.0 & 103.5 & 21.0 & 20.7 & 129.0 & 123.3 & 75.3 & 74.3 & 83.0 & 82.3 & $\begin{array}{l}\text { 9- Leaving } 20 \text { fruiting spurs } x \\
3 \text { eyes }+ \text { seaweed at } 0.2 \%\end{array}$ \\
\hline 107.3 & 103.7 & 21.3 & 21.0 & 129.3 & 123.7 & 75.4 & 74.4 & 83.0 & 82.3 & $\begin{array}{c}10 \text { - Leaving } 20 \text { fruiting spurs } x \\
3 \text { eyes }+ \text { seaweed at } 0.4 \% \\
\end{array}$ \\
\hline 98.0 & 97.0 & 22.5 & 22.1 & 133.3 & 126.0 & 77.8 & 75.9 & 80.1 & 79.0 & $\begin{array}{l}\text { 11- Leaving } 15 \text { fruiting spurs } x \\
4 \text { eyes }\end{array}$ \\
\hline 99.5 & 98.5 & 23.0 & 23.0 & 136.0 & 128.0 & 78.0 & 76.1 & 80.3 & 79.3 & $\begin{array}{l}\text { 12- Leaving } 15 \text { fruiting spurs } x \\
4 \text { eyes }+ \text { seaweed at } 0.05 \%\end{array}$ \\
\hline 101.0 & 100.0 & 24.0 & 23.6 & 138.3 & 129.9 & 78.1 & 76.1 & 80.3 & 79.3 & $\begin{array}{l}\text { 13- Leaving } 15 \text { fruiting spurs } x \\
4 \text { eyes }+ \text { seaweed at } 0.1 \%\end{array}$ \\
\hline 103.5 & 101.6 & 24.0 & 24.0 & 140.0 & 133.6 & 78.1 & 76.2 & 80.3 & 79.4 & $\begin{array}{l}\text { 14- Leaving } 15 \text { fruiting spurs } \mathrm{x} \\
4 \text { eyes }+ \text { seaweed at } 0.2 \% \\
\end{array}$ \\
\hline 104.0 & 102.0 & 24.3 & 24.1 & 140.6 & 133.9 & 78.4 & 76.3 & 80.3 & 79.4 & $\begin{array}{c}15-\text { Leaving } 15 \text { fruiting spurs } x \\
4 \text { eyes }+ \text { seaweed at } 0.4 \% \\
\end{array}$ \\
\hline 1.5 & 1.4 & 1.0 & 1.0 & 1.1 & 1.2 & 1.5 & 1.4 & 2.0 & 1.8 & New L.S.D. at 5\% \\
\hline
\end{tabular}


Table 4. Effect of different fruiting spur length and concentrations of seaweed extract on percentages of $\mathrm{N}, \mathrm{P}, \mathrm{K}, \mathrm{Mg}$ and $\mathrm{Ca}$ in the leaves of Early sweet grapevines during 2014 and 2015 seasons.

\begin{tabular}{|c|c|c|c|c|c|c|c|c|c|c|}
\hline \multicolumn{2}{|c|}{$\begin{array}{c}\text { Leaf Ca } \\
\%\end{array}$} & \multicolumn{2}{|c|}{$\begin{array}{c}\text { Leaf Mg } \\
\%\end{array}$} & \multicolumn{2}{|c|}{ Leaf $K \%$} & \multicolumn{2}{|c|}{$\begin{array}{l}\text { Leaf } P \\
\%\end{array}$} & \multicolumn{2}{|c|}{ Leaf N \% } & \multirow[t]{2}{*}{ Treatments } \\
\hline 2015 & 2014 & 2015 & 2014 & 2015 & 2014 & 2015 & 2014 & 2015 & 2014 & \\
\hline 2.12 & 2.10 & 0.52 & 0.51 & 1.10 & 1.09 & 0.14 & 0.15 & 1.69 & 1.66 & $\begin{array}{l}\text { 1- Leaving } 30 \text { fruiting spurs } x \\
2 \text { eyes }\end{array}$ \\
\hline 2.20 & 2.16 & 0.55 & 0.55 & 1.14 & 1.13 & 0.16 & 0.17 & 1.76 & 1.73 & $\begin{array}{l}\text { 2- Leaving } 30 \text { fruiting spurs } x \\
2 \text { eyes }+ \text { seaweed at } 0.05 \%\end{array}$ \\
\hline 2.27 & 2.22 & 0.58 & 0.59 & 1.17 & 1.17 & 0.19 & 0.19 & 1.72 & 1.80 & $\begin{array}{l}3-\quad \text { Leaving } 30 \text { fruiting spurs } x \\
2 \text { eyes }+ \text { seaweed at } 0.1 \%\end{array}$ \\
\hline 2.35 & 2.36 & 0.61 & 0.64 & 1.20 & 1.22 & 0.21 & 0.21 & 1.80 & 1.90 & $\begin{array}{l}\text { 4- Leaving } 30 \text { fruiting spurs } x \\
2 \text { eyes }+ \text { seaweed at } 0.2 \%\end{array}$ \\
\hline 2.36 & 2.37 & 0.62 & 0.65 & 1.21 & 1.23 & 0.22 & 0.22 & 1.81 & 1.92 & $\begin{array}{ll}5- & \text { Leaving } 30 \text { fruiting spurs } x \\
& 2 \text { eyes }+ \text { seaweed at } 0.4 \%\end{array}$ \\
\hline 2.43 & 2.50 & 0.66 & 0.70 & 1.24 & 1.27 & 0.24 & 0.24 & 1.90 & 2.03 & $\begin{array}{l}\text { 6- Leaving } 20 \text { fruiting spurs } \mathrm{x} 3 \\
\text { eyes }\end{array}$ \\
\hline 2.50 & 2.57 & 0.69 & 0.73 & 1.27 & 1.31 & 0.25 & 0.26 & 1.97 & 1.10 & $\begin{array}{l}\text { 7- Leaving } 20 \text { fruiting spurs } x \\
3 \text { eyes }+ \text { seaweed at } 0.05 \%\end{array}$ \\
\hline 2.57 & 2.65 & 0.72 & 0.76 & 1.31 & 1.34 & 0.27 & 0.28 & 2.05 & 2.18 & $\begin{array}{l}8-\quad \text { Leaving } 20 \text { fruiting spurs } x \\
3 \text { eyes }+ \text { seaweed at } 0.1 \%\end{array}$ \\
\hline 2.64 & 2.72 & 0.75 & 0.80 & 1.36 & 1.37 & 0.28 & 0.30 & 2.13 & 2.27 & $\begin{array}{l}9-\quad \text { Leaving } 20 \text { fruiting spurs } x \\
3 \text { eyes }+ \text { seaweed at } 0.2 \%\end{array}$ \\
\hline 2.65 & 2.74 & 0.76 & 0.81 & 1.37 & 1.38 & 0.29 & 0.30 & 2.14 & 2.28 & $\begin{array}{c}\text { 10- Leaving } 20 \text { fruiting spurs } x \\
3 \text { eyes }+ \text { seaweed at } 0.4 \%\end{array}$ \\
\hline 2.73 & 2.85 & 0.81 & 0.84 & 1.41 & 1.42 & 0.31 & 0.32 & 2.23 & 2.34 & $\begin{array}{l}\text { 11- Leaving } 15 \text { fruiting spurs } \mathrm{x} \\
4 \text { eyes }\end{array}$ \\
\hline 2.81 & 2.93 & 0.84 & 0.88 & 1.44 & 1.46 & 0.33 & 0.34 & 2.31 & 2.41 & $\begin{array}{r}\text { 12- Leaving } 15 \text { fruiting spurs } x \\
4 \text { eyes }+ \text { seaweed at } 0.05 \%\end{array}$ \\
\hline 2.91 & 3.0 & 0.88 & 0.92 & 1.47 & 1.50 & 0.34 & 0.36 & 2.38 & 2.47 & $\begin{array}{c}\text { 13- Leaving } 15 \text { fruiting spurs } x \\
4 \text { eyes }+ \text { seaweed at } 0.1 \%\end{array}$ \\
\hline 2.98 & 3.08 & 0.91 & 0.95 & 1.48 & 1.55 & 0.36 & 0.37 & 2.44 & 2.55 & $\begin{array}{c}\text { 14- Leaving } 15 \text { fruiting spurs } x \\
4 \text { eyes }+ \text { seaweed at } 0.2 \%\end{array}$ \\
\hline 2.99 & 3.09 & 0.92 & 0.96 & 1.49 & 1.56 & 0.37 & 0.38 & 2.46 & 2.56 & $\begin{array}{c}\text { 15- Leaving } 15 \text { fruiting spurs } \mathrm{x} \\
4 \text { eyes }+ \text { seaweed at } 0.4 \%\end{array}$ \\
\hline 0.07 & 0.06 & 0.03 & 0.03 & 0.04 & 0.03 & 0.02 & 0.02 & 0.06 & 0.06 & New L.S.D. at 5\% \\
\hline
\end{tabular}


Table 5. Effect of different fruiting spur lengths and concentrations of seaweed extract on the percentage of berry setting, yield as well as cluster weight and length of Early sweet grapevines during 2014 and 2015 seasons.

\begin{tabular}{|c|c|c|c|c|c|c|c|c|c|c|}
\hline \multicolumn{2}{|c|}{\begin{tabular}{|c|}
$\begin{array}{c}\text { Cluster } \\
\text { length } \\
(\mathrm{cm})\end{array}$ \\
\end{tabular}} & \multicolumn{2}{|c|}{$\begin{array}{c}\text { Cluster } \\
\text { weight (g.) }\end{array}$} & \multicolumn{2}{|c|}{$\begin{array}{c}\text { Yield } \\
/ \text { vine }(\mathbf{k g})\end{array}$} & \multicolumn{2}{|c|}{$\begin{array}{c}\text { No. of clus- } \\
\text { ters / vine }\end{array}$} & \multicolumn{2}{|c|}{$\begin{array}{c}\text { Berry } \\
\text { setting \% }\end{array}$} & \multirow[t]{2}{*}{ Treatments } \\
\hline & & 2015 & 2014 & 2015 & 2014 & 2015 & 2014 & 2015 & 2014 & \\
\hline 26.3 & 25.8 & 381.0 & 380.0 & 13.7 & 12.9 & 36.0 & 34.0 & 9.5 & 9.1 & $\begin{array}{l}\text { 1- Leaving } 30 \text { fruiting spurs } \times 2 \\
\text { eyes }\end{array}$ \\
\hline 26.7 & 26.2 & 390.0 . & 389.0 & 14.8 & 13.2 & 38.0 & 34.0 & 10.2 & 9.8 & $\begin{array}{l}\text { 2- Leaving } 30 \text { fruiting spurs } \times 2 \\
\text { eyes }+ \text { seaweed at } 0.05 \%\end{array}$ \\
\hline 27.0 & 26.5 & $|399.0|$ & 399.0 & 15.2 & 13.6 & 38.0 & 34.0 & 11.0 & 10.6 & $\begin{array}{l}\text { 3- Leaving } 30 \text { fruiting spurs } \times 2 \\
\text { eyes }+ \text { seaweed at } 0.1 \%\end{array}$ \\
\hline 27.3 & 26.8 & 409.0 & 410.0 & 16.4 & 14.0 & 40.0 & 34.0 & 11.6 & 11.2 & $\begin{array}{l}\text { 4- Leaving } 30 \text { fruiting spurs } \times 2 \\
\text { eyes }+ \text { seaweed at } 0.2 \%\end{array}$ \\
\hline 27.4 & 26.9 & 411.0 & 411.0 & 16.4 & 14.0 & 40.0 & 34.0 & 11.7 & 11.3 & $\begin{array}{ll}5- & \text { Leaving } 30 \text { fruiting spurs } \times 2 \\
& \text { eyes }+ \text { seaweed at } 0.4 \%\end{array}$ \\
\hline 25.8 & 25.5 & 368.0 & 370.0 & 11.8 & 12.6 & 32.0 & 34.0 & 8.7 & 8.3 & $\begin{array}{ll}6- & \begin{array}{l}\text { Leaving } 20 \text { fruiting spurs } \mathrm{x} 3 \\
\text { eyes }\end{array}\end{array}$ \\
\hline 26.1 & 25.8 & $|377.0|$ & 379.0 & 12.4 & 12.9 & 33.0 & 34.0 & 9.4 & 9.0 & $\begin{array}{c}7-\begin{array}{l}\text { Leaving } 20 \text { fruiting spurs x } 3 \\
\text { eyes }+ \text { seaweed at } 0.05 \%\end{array}\end{array}$ \\
\hline 26.4 & 26.1 & 386.0 & 388.0 & 13.1 & 13.2 & 34.0 & 34.0 & 10.0 & 9.6 & $\begin{array}{ll}8- & \text { Leaving } 20 \text { fruiting spurs } \times 3 \\
& \text { eyes }+ \text { seaweed at } 0.1 \%\end{array}$ \\
\hline 26.7 & 26.4 & 395.0 & 398.0 & 13.8 & 13.5 & 35.0 & 34.0 & 10.5 & 10.2 & $\begin{array}{ll}9- & \text { Leaving } 20 \text { fruiting spurs } \times 3 \\
& \text { eyes }+ \text { seaweed at } 0.2 \%\end{array}$ \\
\hline 26.7 & 26.5 & 396.0 & 399.0 & 13.9 & 13.6 & 35.0 & 34.0 & 10.8 & 10.3 & $\begin{array}{c}\text { 10- Leaving } 20 \text { fruiting spurs x } 3 \\
\text { eyes }+ \text { seaweed at } 0.4 \%\end{array}$ \\
\hline 25.2 & 25.2 & 355.0 . & 357.0 & 10.7 & 11.8 & 30.0 & 33.0 & 8.0 & 7.5 & $\begin{array}{l}\begin{array}{l}11-\text { Leaving } 15 \text { fruiting spurs } \mathrm{x} 4 \\
\text { eyes }\end{array}\end{array}$ \\
\hline 25.5 & 25.5 & 365.0 & 366.0 & 11.3 & 12.1 & 31.0 & 33.0 & 8.7 & 8.1 & $\begin{array}{c}\text { 12- Leaving } 15 \text { fruiting spurs } \mathrm{x} 4 \\
\text { eyes }+ \text { seaweed at } 0.05 \%\end{array}$ \\
\hline 25.8 & 25.8 & 375.0 & 376.0 & 12.0 & 12.4 & 32.0 & 33.0 & 9.4 & 8.7 & $\begin{array}{c}\text { 13- Leaving } 15 \text { fruiting spurs } \times 4 \\
\text { eyes }+ \text { seaweed at } 0.1 \%\end{array}$ \\
\hline 26.1 & 26.1 & $|384.0|$ & 385.0 & 12.3 & 12.7 & 32.0 & 33.0 & 10.5 & 9.5 & $\begin{array}{c}\text { 14- Leaving } 15 \text { fruiting spurs } \mathrm{x} 4 \\
\text { eyes }+ \text { seaweed at } 0.2 \%\end{array}$ \\
\hline 26.5 & 26.2 & 385.0 & 386.0 & 12.3 & 12.7 & 32.0 & 33.0 & 10.6 & 9.6 & $\begin{array}{c}\text { 15- Leaving } 15 \text { fruiting spurs } \mathrm{x} 4 \\
\text { eyes }+ \text { seaweed at } 0.4 \%\end{array}$ \\
\hline 0.3 & 0.3 & 8.8 & 9.0 & 0.4 & 0.3 & 2.0 & NS & 0.7 & \begin{tabular}{l|l}
0.6 & 1
\end{tabular} & New L.S.D. at 5\% \\
\hline
\end{tabular}


Table 6. Effect of different fruiting spur lengths and concentrations of seaweed extract on percentage of cluster shoulder, shot berries as well as berry weight and diameter of Early sweet grapevines during 2014 and 2015 seasons.

\begin{tabular}{|c|c|c|c|c|c|c|c|c|c|c|}
\hline \multicolumn{2}{|c|}{$\begin{array}{c}\text { Berry } \\
\text { equatorial } \\
(\mathrm{cm})\end{array}$} & \multicolumn{2}{|c|}{$\begin{array}{l}\text { Berry lon- } \\
\text { gitudinal } \\
(\mathrm{cm})\end{array}$} & \multicolumn{2}{|c|}{$\begin{array}{l}\text { Berry } \\
\text { weight } \\
\text { (g.) }\end{array}$} & \multicolumn{2}{|c|}{$\begin{array}{c}\text { Shot ber- } \\
\text { ries } \%\end{array}$} & \multicolumn{2}{|c|}{$\begin{array}{c}\text { Cluster } \\
\text { shoulder } \\
\text { (cm) }\end{array}$} & \multirow[t]{2}{*}{ Treatments } \\
\hline & & 2015 & 2014 & 2015 & 2014 & 2015 & 2014 & 2015 & 2014 & \\
\hline 1.69 & 1.72 & 2.16 & 2.18 & 4.67 & 4.71 & 7.9 & 8.1 & 16.3 & 16.1 & $\begin{array}{l}\text { 1- Leaving } 30 \text { fruiting spurs x } 2 \\
\text { eyes }\end{array}$ \\
\hline 1.74 & 1.77 & 2.23 & 2.25 & 4.74 & 4.80 & 7.5 & 7.7 & 16.6 & 16.4 & $\begin{array}{l}\text { 2- } \begin{array}{l}\text { Leaving } 30 \text { fruiting spurs } \times 2 \\
\text { eyes }+ \text { seaweed at } 0.05 \%\end{array}\end{array}$ \\
\hline 1.78 & 1.82 & 2.30 & 2.33 & 4.81 & 4.88 & 7.1 & 7.3 & 16.8 & 16.7 & 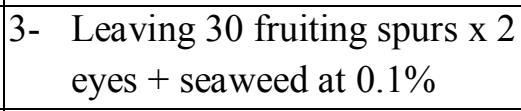 \\
\hline 1.82 & 1.88 & 2.36 & 2.40 & 4.90 & 4.96 & 6.7 & 6.9 & 17.0 & 17.0 & $\begin{array}{ll}4- & \text { Leaving } 30 \text { fruiting spurs } \times 2 \\
& \text { eyes }+ \text { seaweed at } 0.2 \%\end{array}$ \\
\hline 1.83 & 1.89 & 2.37 & 2.41 & 4.91 & 4.97 & 6.6 & 6.8 & 17.1 & 17.1 & 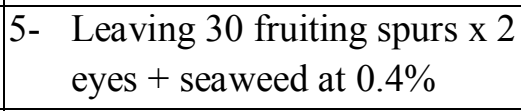 \\
\hline 1.88 & 1.94 & 2.43 & 2.50 & 4.97 & 5.10 & 6.2 & 6.4 & 15.9 & 15.8 & $\begin{array}{ll}6- & \begin{array}{l}\text { Leaving } 20 \text { fruiting spurs } \mathrm{x} 3 \\
\text { eyes }\end{array} \\
\end{array}$ \\
\hline 1.93 & 1.99 & 2.50 & 2.55 & 5.05 & 5.18 & 5.8 & 6.0 & 16.1 & 16.1 & $\begin{array}{ll}7- & \text { Leaving } 20 \text { fruiting spurs x } 3 \\
& \text { eyes }+ \text { seaweed at } 0.05 \%\end{array}$ \\
\hline 1.99 & 2.06 & 2.57 & 2.61 & 5.12 & 5.27 & 5.4 & 5.6 & 16.4 & $16.4^{8}$ & \begin{tabular}{|ll}
$8-$ & Leaving 20 fruiting spurs x 3 \\
& eyes + seaweed at $0.1 \%$
\end{tabular} \\
\hline 2.05 & 2.11 & 2.64 & 2.66 & 5.20 & 5.36 & 4.8 & 5.0 & 16.6 & 16.6 & 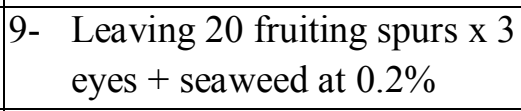 \\
\hline 2.06 & 2.12 & 2.65 & 2.67 & 5.21 & 5.37 & 9.7 & 4.9 & 16.7 & 16.7 & $\begin{array}{c}\text { 10- Leaving } 20 \text { fruiting spurs x } 3 \\
\text { eyes }+ \text { seaweed at } 0.4 \%\end{array}$ \\
\hline 2.12 & 2.20 & 2.72 & 2.74 & 5.30 & 5.46 & 4.1 & 4.3 & 15.6 & 15.8 & $\begin{array}{l}\text { 11- Leaving } 15 \text { fruiting spurs x } 4 \\
\text { eyes }\end{array}$ \\
\hline 2.19 & 2.25 & 2.79 & 2.79 & 5.37 & 5.54 & 3.8 & 4.0 & 15.8 & 16.0 & $\begin{array}{c}\text { 12- Leaving } 15 \text { fruiting spurs x } 4 \\
\text { eyes }+ \text { seaweed at } 0.05 \%\end{array}$ \\
\hline 2.26 & 2.30 & 2.88 & 2.84 & 5.44 & 5.63 & 3.2 & 3.6 & 16.0 & $16.2^{1}$ & $\begin{array}{c}\text { 13- Leaving } 15 \text { fruiting spurs x } 4 \\
\text { eyes }+ \text { seaweed at } 0.1 \%\end{array}$ \\
\hline 2.32 & 2.36 & 2.94 & 2.89 & 5.52 & 5.72 & 3.0 & 3.2 & 16.3 & $16.5^{1}$ & $\begin{array}{c}\text { 14- Leaving } 15 \text { fruiting spurs } \times 4 \\
\text { eyes }+ \text { seaweed at } 0.2 \%\end{array}$ \\
\hline 2.33 & 2.37 & 2.95 & 2.90 & 5.63 & 5.73 & 2.9 & 3.1 & 16.4 & $16.6^{1}$ & $\begin{array}{c}\text { 15- Leaving } 15 \text { fruiting spurs x } 4 \\
\text { eyes }+ \text { seaweed at } 0.4 \%\end{array}$ \\
\hline 0.05 & 0.04 & 0.06 & 0.05 & 0.07 & 0.08 & 0.4 & 0.4 & 0.2 & 0.2 & New L.S.D. at 5\% \\
\hline
\end{tabular}


Table 7. Effect of different fruiting spur length and concentrations of seaweed extract on some chemical characteristics of the berries of Early sweet grapevines during 2014 and 2015 seasons.

\begin{tabular}{|c|c|c|c|c|c|c|c|c|}
\hline \multicolumn{2}{|c|}{$\begin{array}{l}\text { Total sug- } \\
\text { ars } \%\end{array}$} & \multicolumn{2}{|c|}{$\begin{array}{c}\text { T.S.S/ } \\
\text { acid }\end{array}$} & \multicolumn{2}{|c|}{$\begin{array}{c}\text { Total acid- } \\
\text { ity \% }\end{array}$} & \multicolumn{2}{|c|}{ T.S.S\% } & \multirow[t]{2}{*}{ Treatments } \\
\hline 2015 & 2014 & 2015 & 2014 & 2015 & 2014 & 2015 & 2014 & \\
\hline 14.5 & 14.8 & 25.2 & 25.4 & 0.706 & 0.710 & 17.8 & 18.0 & 1- Leaving 30 fruiting spurs $\mathrm{x} 2$ eyes \\
\hline 14.6 & 15.2 & 26.4 & 26.5 & 0.686 & 0.690 & 18.1 & 18.3 & $\begin{array}{l}\text { 2- Leaving } 30 \text { fruiting spurs } \times 2 \text { eyes + sea- } \\
\text { weed at } 0.05 \%\end{array}$ \\
\hline 15.2 & 15.5 & 27.6 & 27.8 & 0.666 & 0.670 & 18.4 & 18.6 & $\begin{array}{l}\text { 3- Leaving } 30 \text { fruiting spurs } \times 2 \text { eyes + sea- } \\
\text { weed at } 0.1 \%\end{array}$ \\
\hline 15.5 & 15.8 & 28.9 & 29.2 & 0.646 & 0.674 & 18.7 & 18.9 & $\begin{array}{l}\text { 4- Leaving } 30 \text { fruiting spurs } \times 2 \text { eyes }+ \text { sea- } \\
\text { weed at } 0.2 \%\end{array}$ \\
\hline 15.6 & 15.9 & 29.1 & 29.5 & 0.645 & 0.645 & 18.8 & 19.0 & $\begin{array}{l}\text { 5- Leaving } 30 \text { fruiting spurs } \times 2 \text { eyes + sea- } \\
\text { weed at } 0.4 \%\end{array}$ \\
\hline 16.0 & 16.3 & 30.7 & 31.1 & 0.625 & 0.620 & 19.2 & 19.3 & 6- $\quad$ Leaving 20 fruiting spurs $x 3$ eyes \\
\hline 16.3 & 16.6 & 32.3 & 32.7 & 0.603 & 0.600 & 19.5 & 19.6 & 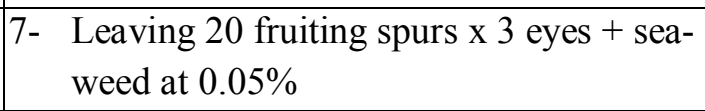 \\
\hline 16.6 & 17.0 & 34.0 & 43.5 & 0.583 & 0.580 & 19.8 & 20.0 & $\begin{array}{l}8-\quad \text { Leaving } 20 \text { fruiting spurs x } 3 \text { eyes }+ \text { sea- } \\
\text { weed at } 0.1 \%\end{array}$ \\
\hline 17.0 & 17.6 & 33.7 & 36.3 & 0.564 & 0.560 & 19.0 & 20.3 & $\begin{array}{l}\text { 9- Leaving } 20 \text { fruiting spurs } \times 3 \text { eyes }+ \text { sea- } \\
\text { weed at } 0.2 \%\end{array}$ \\
\hline 17.1 & 17.7 & 33.9 & 36.5 & 0.563 & 0.559 & 19.1 & 20.4 & $\begin{array}{l}\text { 10- Leaving } 20 \text { fruiting spurs } \times 3 \text { eyes + sea- } \\
\text { weed at } 0.4 \%\end{array}$ \\
\hline 17.4 & 18.0 & 37.3 & 38.3 & 0.523 & 0.540 & 19.5 & 20.7 & 11- Leaving 15 fruiting spurs $\mathrm{x} 4$ eyes \\
\hline 17.8 & 18.3 & 39.4 & 40.5 & 0.503 & 0.518 & 19.8 & 21.0 & $\begin{array}{l}\text { 12- Leaving } 15 \text { fruiting spurs } x 4 \text { eyes }+ \text { sea- } \\
\text { weed at } 0.05 \%\end{array}$ \\
\hline 18.2 & 18.6 & 39.8 & 42.6 & 0.480 & 0.500 & 19.1 & 21.3 & $\begin{array}{l}\text { 13- Leaving } 15 \text { fruiting spurs } x 4 \text { eyes }+ \text { sea- } \\
\text { weed at } 0.1 \%\end{array}$ \\
\hline 18.6 & 18.9 & 41.9 & 45.0 & 0.463 & 0.480 & 19.4 & 21.6 & $\begin{array}{l}\text { 14- Leaving } 15 \text { fruiting spurs } \mathrm{x} 4 \text { eyes }+ \text { sea- } \\
\text { weed at } 0.2 \%\end{array}$ \\
\hline 18.7 & 19.0 & 42.1 & 45.3 & 0.463 & 0.479 & 19.5 & 21.7 & $\begin{array}{l}\text { 15- Leaving } 15 \text { fruiting spurs } \mathrm{x} 4 \text { eyes }+ \text { sea- } \\
\text { weed at } 0.4 \%\end{array}$ \\
\hline 0.3 & 0.3 & 0.9 & $\begin{array}{ll}0.9 \\
\end{array}$ & 0.017 & 0.018 & 0.3 & 0.3 & New L.S.D. at 5\% \\
\hline
\end{tabular}

\section{References:}

Abdel-Fattah S.E; Marwad, I.A; and Isis Abdelshahied,R (1993).Effect of bud load and spur length on Roumi Red grapevine I-Weight of pruning and chemical composition of 1 year - old wood. Zagazig .J. Agric. Res 2: (6) pp 1889 -1899.

Abdel-Mohsen, M.A. (2013): Application of various pruning treatments for improving productivity and
Abd El- Hameed, H.M., Abada, M.A. and Seleem- Basma, M. (2010): Reducing inorganic $\mathrm{N}$ fertilizer partially by using yeast, seaweed and farmyard manure extracts in Flame seedless grapevines. Minia $2^{\text {nd }}$ Conf. Agric. Environ Sci. pp. 81-89.

fruit quality of crimson seedless grapevine. World Journal of Agricultural Sciences 9 (5): 377-382. 
Abd El-Wahab, A.M., (2007). Effect of some sodium azide and algae extract treatments on vegetative growth, yield and berries quality of Early Superior grapevine cv. M.Sc. Thesis Fac. of Agric., Minia Univ. Egypt.

Ahmed-Ansam, S. (2002): Effect of cane length on bud behavior, growth and productivity of "Superior" grapevines. M.Sc. Thesis, Fac.of Agric. Cairo Univ. Egypt.

Ahmed, F. F. and Morsy, M. H. (1999): A new method for measuring leaf area in different fruit species. Minia J. Agric Res. \& Develop. Vol. (19) pp 97-105.

Association of Official Agricultural Chemists (2000): Official Methods of Analysis $14^{\text {th }}$ ed. (A.O.A.C.) Benjamin Franklin Station, Washington D.C.U.S.A., pp. 490-510.

Awad, N.A.E. (2003): Studies on pruning severity of Thompson seedless grapes. M. Sc. Thesis Fac. of Agric. Mansoura Univ. Egypt.

El-Saman, A.Y.E. (2010): Response of Flame seedless grapevines growing under El-Mataana conditions to spraying seaweed extract. M.Sc. Thesis Fac. of Agric. Minia Univ. Egypt.

Gad El- Kareem, M.R. and Abd ElRahman, M.M.A. (2013): Response of Ruby seedless grapevines to foliar application of seaweed extract, salicylic acid and Roselle extract. Hort. Sci. J. of Suez Canal Univ. vol. (1): 299303.

James, B. (1994): Chapters from life. Ann. Rev. Physiol. Plant. Mol. Biolog. 4:1- 23.

Jarad, A. (2004): Effect of fruit canes and eyes vine load on the productivity of a local grape variety under the conditions of Deir El- Zor city. Bull Fac. Agric. Cairo Univ, 55: 603-608.
Kamel, M.K. (2002): Physiological studies on pruning and fertilization of Flame seedless grapevines. ( $V$. vinifera L.). Ph. D. Thesis. Fac. of Agric. Minia Univ. Egypt.

Mead, R., Curnow, R. N. and Harted, A. M. ( 1993 ). Statistical methods in Agricultural and Experimental Biology. $2^{\text {nd }}$ Ed. Chapman \& Hall, London pp. 10-44.

Nejatian, M.A. (2003): Effects of bud number and cane length on bud fertility and some characteristics of grapevine cv. Bidanehsefid, 19(4): 457-467.

Ranspise, S. A.; Patil, B. T.; More, T. A.; Birade, R. M.; Ghure, T. K., (2003): Effect of sub-cane pruning on fruitfulness and yield of grape cv Thompson seedless. Journal of Maharashtra Agricultural Universities.27 3: 258259.

Seleem-Basma, M. and Ahmed, F.F. (2008): The promotive effect of seaweed extract on fruiting of thompson seedless grapevines. Minia Journal of Agricultural Research and Development 28 (1): 60- 80 .

Summer, (1985): Diagnosis and Recommendation Integrated system (DRIS) as a guide to orchard fertilization Hon. Abst. 55(8):7502.

Tamura, F.; Muraya, K. and Fujji, Y. (2002): Effects of short cane pruning in summer and long cane pruning in winter on growth and yield of the grapevine "Muscat" of Alexandria' in forcing culture condition. Hort. Res. (Japan), 1(4): 269274. (Hort. Abst., 73(5): 4269).

Wilde, S.A.; Corey, R.B.; Layer, J.G. and Voigt, G.K. (1985): Soils and Plant Analysis for Tree Culture. Oxford, and 1131-1, publishing Co., New Delhi, pp. 96-106. 
تأثير طول الابرة الثمرية ورش مستخلص الأعشاب البحرية على كمية المحصول وجودة

$$
\begin{aligned}
& \text { الحبات فى كرمات العنب الأيرلي سويت البحرية علي كمي } \\
& \text { علي حسن علي سيد - مؤمن علي خلف محمد } \\
& \text { قسم البساتين - كلية الزر اعة - جامعة المنيا - مصر }
\end{aligned}
$$

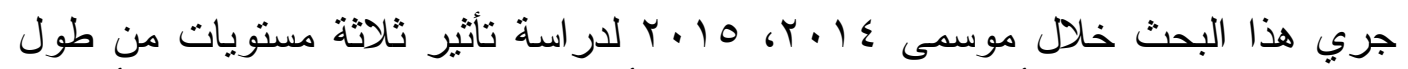

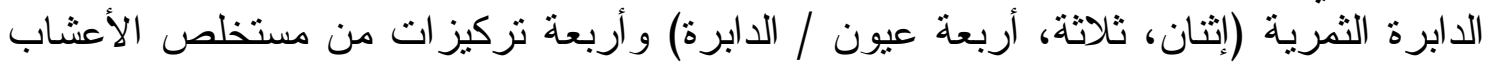

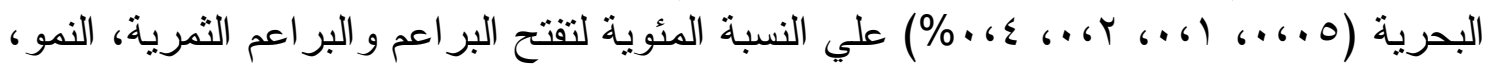

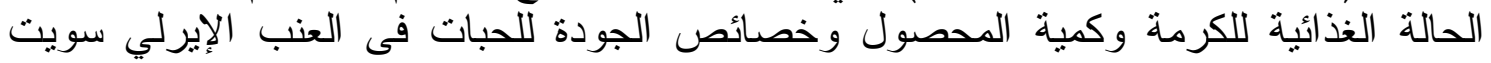
النامى تحت ظروف منطقة المنيا.

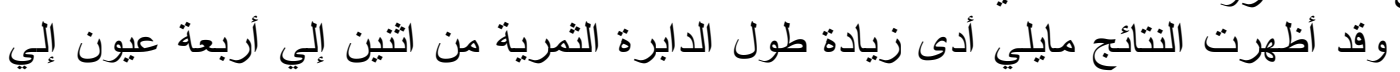

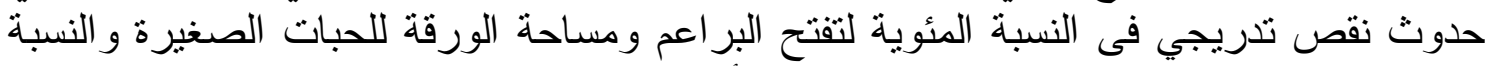

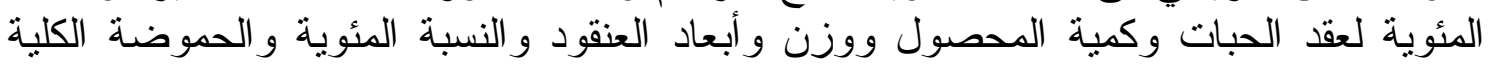

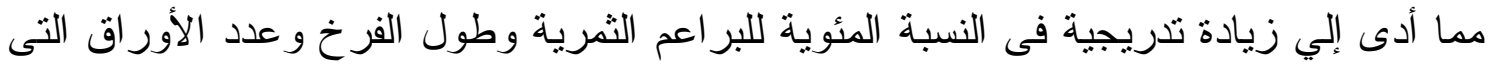

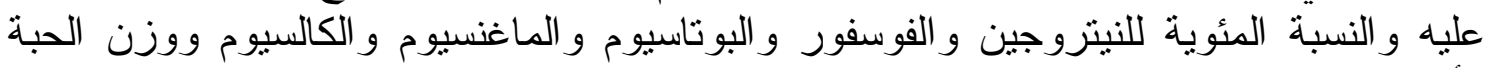

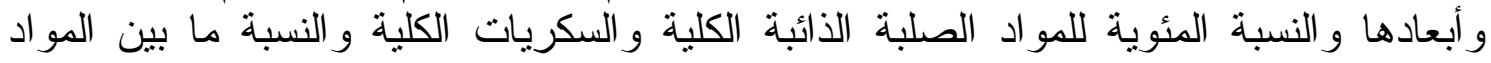

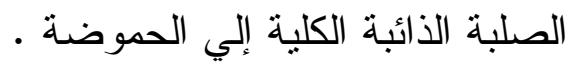

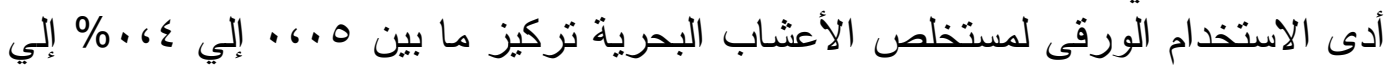

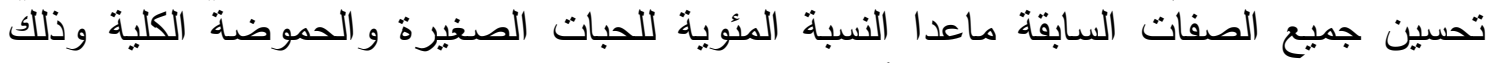

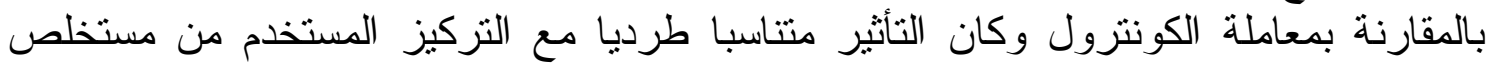

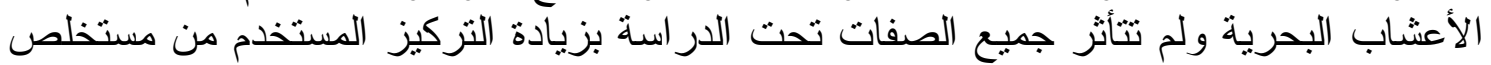

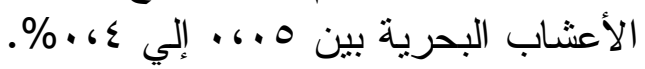
من نتائج الدر اسة يمكن التوصية بأنه

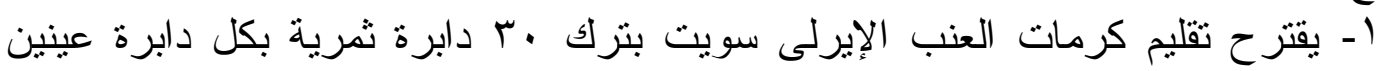

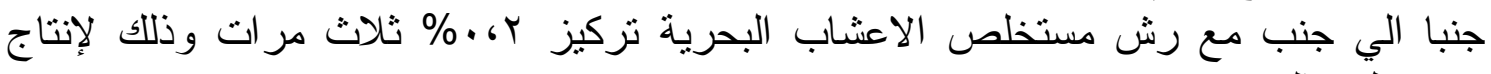
محصول عالي.

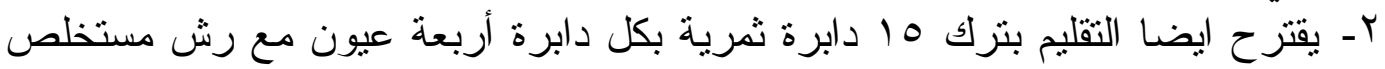

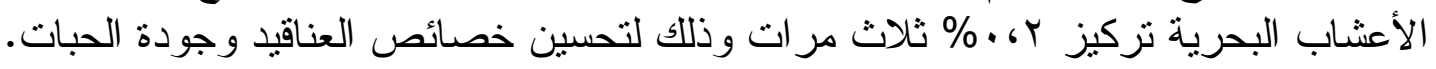

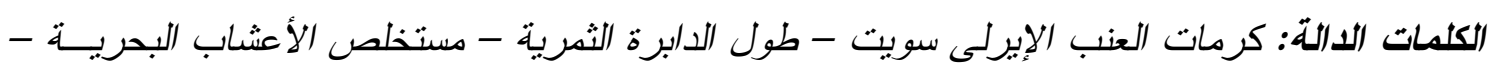
كمبية المحصول وخصائص الجودة للحبات. لإليرل 